\title{
Factors Affecting Hemagglutinations Strength in ABO Blood Group Typing Test Using the Tube Method
}

You La Jeon ${ }^{1}$, Woo-In Lee $^{1,2}$, So Young Kang ${ }^{1,2}$, and Myeong Hee Kim ${ }^{1,2}$ ${ }^{1}$ Department of Laboratory Medicine, Kyung Hee University Hospital at Gangdong; ${ }^{2}$ Department of Laboratory Medicine, Kyung Hee University School of Medicine, Seoul, Korea

Corresponding author: Woo-In Lee

Department of Laboratory Medicine, Kyung Hee University Hospital at Gangdong, 892 Dongnam-ro, Gangdong-gu, Seoul 05278, Korea Tel: $+82-2-440-7190$ Fax: +82-2-440-7195

E-mail: wileemd@khu.ac.kr
Background: The $\mathrm{ABO}$ blood group typing test ( $\mathrm{ABO}$ test) is an initial pre-transfusion test based on hemagglutination. Although various factors affect hemagglutination strength, few studies have examined how these factors can be applied in clinical laboratories and their effects on hemagglutination. This study was conducted to analyze the factors affecting hemagglutination strength in the $\mathrm{ABO}$ test using a tube method applied in many laboratories.

Methods: We conducted a detailed questionnaire survey of 51 laboratories which use the $\mathrm{ABO}$ test with a tube method. We also analyzed the results of the $\mathrm{ABO}$ test (cell and serum typing) with 40 specimens using factors affecting hemagglutination at a tube method and applied differently in each laboratory.

Results: Each laboratory used various methods to prepare red cell suspensions as specimens or reagents and used different reagent to sample ratios, centrifugation protocols, and shaking test tubes before evaluating hemagglutination strength. By testing various combinations of these factors, direct sampling from the red cell layer of the original specimen was found to have the largest effect on lowering hemagglutination strength in cell typing tests. In serum typing tests, various factors influenced hemagglutination strength, including shaking the tube before analysis and the concentration of a home-made red cell suspension used as a reagent.

Conclusions: To achieve accurate results in the ABO test by the tube method, detailed guidelines that include the factors affecting hemagglutination strength determined in this study should be established.

(J Lab Med Qual Assur 2018;40:161-170)

Key Words: Blood group typing test, Hemagglutination strength, Tube method, Red cell suspension

Received June 28, 2018, Revision received August 15, 2018, Accepted August 20, 2018

\section{서론}

$\mathrm{ABO}$ 및 $\mathrm{D}$ 혈액형 검사, 비예기항체 선별 및 동정검사, 교차 시험 등과 같은 수혈 전 검사는 안전한 수혈을 위해 반드시 정 확하게 이루어져야 한다[1]. 그 중 $\mathrm{ABO}$ 및 $\mathrm{D}$ 혈액형 검사는 가장 먼저 시행되는 수혈 전 검사로서 환자의 연령이나 질환, 자가 또는 동종항체에 따른 영향이 있을 수 있으나 검사를 시 행하는 기관이나 검사방법에 상관없이 동일하게 정확한 결과 가 보고되어야 하는 매우 중요한 검사이다[2]. 최근 자동화장 비의 도입이 활발하지만, 슬라이드나 시험관을 이용하는 수기
법이 다수의 기관에서 사용되고 있고, 자동화장비를 사용하는 기관에서도 수기법을 보조검사방법으로 사용하고 있으며, 이 모든 검사는 혈구응집을 기본으로 하고 있다.

2015년도 혈액원 대상 ABO 및 D혈액형 검사 외부 숙련도 조사 사업보고에 따르면 참여기관의 다수(63.2\%)가 혈구형 과 혈청형 검사 모두를 시험관법으로 시행하고 있으며, $27.9 \%$ 의 기관은 혈구형은 슬라이드법으로, 혈청형 검사는 시험관법 으로 검사를 하고 있다[3]. 시험관법은 슬라이드법에 비해 더 민감하며 적혈구 응집강도를 정확히 판단할 수 있다는 장점이 있어 수기법으로 많이 사용되고 있음에도 불구하고[2], 혈청 


\section{Journal of LABORATORY MEDICINE and QUALITY ASSURANCE}

\section{You La Jeon et al • Factors for Hemagglutinations in Tube Method}

형 검사의 경우 동일한 검체에 대해 $1+$ 에서 $4+$ 까지 기관마 다 다양한 응집결과를 보고하고 있는 실정이다[3]. 그 원인으 로 생각할 수 있는 것은 응집강도 판독기준이나 판독경험의 부 족뿐 아니라 시험관법의 검사방법 등이 있다.

시험관법을 이용한 $\mathrm{ABO}$ 혈액형 검사의 검사과정 중 혈구응 집에 영향을 미칠 수 있는 요인으로는 시험관 재질이나 검체종 류와 양, 원심방법 등이 있다[4-6]. 그러나 최근 검사를 시행하 는 기관마다 이와 같은 요인들을 어떻게 적용하고 있는지에 대 한 실제적인 자료가 없고, 다양한 요인들의 조합으로 수혈 전 검사를 시행했을 때 혈구응집에 미치는 영향에 대해서도 보고 된 바가 없다. 따라서 본 연구에서는 이에 대한 자료를 조사하 고, 혈구 응집강도와의 연관성을 분석하여 시험관법을 이용한 $\mathrm{ABO}$ 혈액형 검사를 시행하는 기관에서 보다 통일된 방법으로 검사를 수행할 수 있도록 기초자료를 제공하고자 한다.

\section{재료 및 방법}

본 연구는 일차적으로 설문을 통한 조사를 시행하였고, 이차 적으로 혈구형 및 혈청형 검사방법이나 과정에 대한 설문의 응 답유형 중 빈도가 높은 유형을 조합하여 실험하였다.

\section{1. 설문조사의 대상 및 내용}

혈구형 또는 혈청형 검사에 시험관법을 사용하거나 자동화 장비를 사용하지만 보조검사로 시험관법을 사용하고 있는 의 료기관 중 52 개 기관을 대상으로 하였으며, 대상기관에 이메 일로 설문을 전송하고, 답변은 담당 전문의 또는 담당 병리사 가 작성하도록 하였다. 회신된 설문 중 불확실한 항목은 전화 문의로 확인하였다. 설문은 2017년 6월부터 9월말까지 시행하 였으며, 최소 50 개 기관으로부터 설문에 대한 회신을 받는 것 을 목표로 하였다.

설문은 크게 혈액은행검사실 현황, 혈구형 검사, 혈청형 검 사로 구성하였다. 혈액은행검사실 현황에 대한 문항은 $\mathrm{ABO}$ 혈액형 검사건수, 검사자 인력구성, 내부교육 횟수, 응집강도 판독을 위한 이미지 부착 여부, 검사실 내 온도와 습도, 원심분 리기 제조사와 모델 등으로 구성하였다. 혈구형 검사와 혈청형 검사문항은 각각 검체 용기, 검사 전 검체 보관온도, 검사 시행 전까지 소요시간, 시험관 재질, 규격, 검사용 또는 시약용 혈구 부유액 제조방법, 시약의 제조사 및 사용용량, 원심방법, 원심 후 시험관 관찰방법, 판독방법, 응집강도 표기방법 등의 질문 으로 구성하였다.

\section{2. 실험}

본 연구를 위한 실험은 2017년 10월 중에 시행하였으며, 설 문조사 내용을 바탕으로 혈구형 및 혈청형 검사 각각에 대한 변수를 지정하고, 혈액형 검사를 위해 의뢰된 검체의 잔여검 체를 사용하였으며, 잔여검체가 발생할 때마다 실험하였다. 혈 구형 검사는 6 개 변수의 세부사항을 조합하여 10 가지 실험조 건을 조성하였으며, 각각 조건마다 40 개의 동일한 검체로 총 400 회의 실험을 시행하였다. 혈청형 검사는 7 개 변수의 변수 의 세부사항을 조합하여 11 가지 실험조건을 조성하였고, 각 각의 조건에 따라 30 개의 동일한 원검체와 10 개의 2 배 희석한 검체로 총 440회의 실험을 시행하였다. 혈구형 실험에서는 $\mathrm{A}$, $\mathrm{B}$ 항원이 발현되어 있지 않은 $\mathrm{O}$ 형 검체를, 혈청형 실험에서는 항-A, B 항체가 없는 $\mathrm{AB}$ 형 검체를 배제하고 다양한 혈액형이 구성되도록 하였다.

혈구형 검사의 6 개 변수는 시험관의 재질(유리/플라스틱), 혈구액 채취방법(식염수 세척 후 식염수 혼합하여 $2 \%-5 \%$ 혈 구부유액; 혈구층과 혈청을 혼합하여 채취; 혈구층에서 직 접 채취), 시약(Sihdia [Shingyang Diagnostics, Siheung, Korea]; Novaclone [Dominion Biologicals, Dartmouth, Canada]), 혈구액 대 시약의 비(1:1/1:2), 원심분리방법 (3,000 rpm, 15 seconds; 2,000 rpm, 15 seconds), 원심 후 단순 침전과 구분하기 위해 시험관을 흔드는 방법 $\left(>30^{\circ} 1-4\right.$ 회; $>30^{\circ} 5-10$ 회; $<30^{\circ} 1-4$ 회; $<30^{\circ}$ 5-10회)이며, 각각의 변 수를 조합한 내용은 Table 1에 제시하였다. 설문조사에서 가 장 많이 사용된 항혈청시약은 Bioscot (Millipore, Livingston, UK) 제품이지만 2017년 중반 이후 수입이 중단된 상태로 실 험에 포함시킬 수 없었다.

혈청형 검사의 6 개 변수는 검체의 종류(혈청/혈장), 시험관 의 재질(유리/플라스틱), 자가제조 혈구시약의 농도와 사용기 간(제조 당일 $3.85 \%$; 제조 후 7일째 3.85\%; 제조 당일 $2 \%$; 제조 당일 $5 \%$ ), 혈구시약 대 검체 비율( $1: 1 / 1: 2)$, 원심분리방 법(3,000 rpm, 15 seconds; 2,000 rpm, 15 seconds), 원심 후 단순 침전과 구분하기 위해 시험관을 흔드는 방법 $\left(<30^{\circ} 1-4\right.$ 회; <30 5-10회; $>30^{\circ} 1-4$ 회; $>30^{\circ} 5-10$ 회)이며, 각각의 변 수를 조합한 내용은 Table 2에 제시하였다. 혈청형 실험에서 총 40 개의 검체 중 10 검체는 항체 역가가 낮을 경우를 보기 위 해 혈청을 2 배 희석하여 실험하였다.

각 조합대로 시행한 실험의 결과는 강동경희대학교병원에 서 시행 중인 방법(혈구형: 유리시험관; 식염수 세척 후 식염 수 혼합하여 2\%-5\% 농도 혈구부유액; 혈구시약 대 검체 비 율 1:1; 원심분리 3,000 rpm, 15 seconds; 원심 후 > 30 5-10 회 흔든 후 응집강도 관찰; 혈청형: 혈청/유리시험관/자가제 
Journal of LABORATORY MEDICINE and QUALITY ASSURANCE

You La Jeon et al • Factors for Hemagglutinations in Tube Method

Table 1. Combination of various factors affecting hemagglutination in cell typing ( 40 specimens)

\begin{tabular}{|c|c|c|c|c|c|c|}
\hline No. & Tube & Red cell suspension as specimen & $\begin{array}{c}\text { Antisera } \\
\text { reagent }\end{array}$ & $\begin{array}{l}\text { Ratio of specimens } \\
\text { and reagent }\end{array}$ & $\begin{array}{l}\text { Centrifugation } \\
\quad(\mathrm{rpm}, \mathrm{sec})\end{array}$ & $\begin{array}{l}\text { Shaking tube before } \\
\text { interpretation } \\
\text { (angle, times) }\end{array}$ \\
\hline $1^{*}$ & Glass & $2 \%-5 \%$ with saline & SIHDIA & $1: 1$ & $3,000,15$ & $>30^{\circ}, 5-10$ \\
\hline 2 & Glass & $2 \%-5 \%$ with saline & SIHDIA & $1: 1$ & $3,000,15$ & $>30^{\circ}, 1-4$ \\
\hline 3 & & & & & & $<30^{\circ}, 1-4$ \\
\hline 4 & & & & & & $<30^{\circ}, 5-10$ \\
\hline 6 & & & & $1: 2$ & $3,000,15$ & \\
\hline 7 & & & NOVA & $1: 1$ & & \\
\hline 8 & & Mixed with serum and red cell layer & SIHDIA & & & \\
\hline 9 & & Direct sampling from the red cell layer & & & & \\
\hline
\end{tabular}

*This is the method performed by our laboratory.

Table 2. Combination of various factors affecting hemagglutination in serum typing (40 specimens; 30 original specimens and 10 diluted specimens)

\begin{tabular}{|c|c|c|c|c|c|c|c|}
\hline No. & Tube & $\begin{array}{l}\text { Red cell } \\
\text { suspension as } \\
\text { reagent }(\%)\end{array}$ & Days* & $\begin{array}{l}\text { Specimen } \\
\text { (serum or } \\
\text { plasma) }\end{array}$ & $\begin{array}{c}\text { Ratio of reagent } \\
\text { and specimen }\end{array}$ & $\begin{array}{l}\text { Centrifugation } \\
\quad(\mathrm{rpm}, \mathrm{sec})\end{array}$ & $\begin{array}{l}\text { Shaking tube before } \\
\text { interpretation } \\
\text { (angle, times) }\end{array}$ \\
\hline $1^{\dagger}$ & Glass & 3.85 & 0 & Serum & $1: 2$ & $3,000,15$ & $<30^{\circ}, 1-4$ \\
\hline 2 & Glass & 3.85 & 0 & Serum & $1: 2$ & $3,000,15$ & $<30^{\circ}, 5-10$ \\
\hline 3 & & & & & & & $>30^{\circ}, 1-4$ \\
\hline 4 & & & & & & & $>30^{\circ}, 5-10$ \\
\hline 5 & & & & & & $2,000,15$ & $<30^{\circ}, 1-4$ \\
\hline 6 & & & & & $1: 1$ & $3,000,15$ & \\
\hline 7 & & & & Plasma & $1: 2$ & & \\
\hline 8 & & & 7 & Serum & & & \\
\hline 9 & & 2 & 0 & & & & \\
\hline 10 & & 5 & & & & & \\
\hline 11 & Plastic & 3.85 & & & & & \\
\hline
\end{tabular}

${ }^{\star}$ Days elapsed from the day of preparation of rec cell suspension. ${ }^{\dagger}$ This is the method performed by our laboratory.

조 혈구시약 $3.85 \%$ 당일제조 후 사용; 혈구시약 대 검체 비율 $1: 2$; 원심분리 $3,000 \mathrm{rpm}, 15 \mathrm{~seconds}$; 원심 후 < $30^{\circ} 1$-4회 흔든 후 응집강도 관찰)을 기준으로 하여 응집정도(음성[-], trace[士] 약 4+)를 비교하였다. 원심분리기는 DIACENT-12 (DiaMed, Cressier, Switzerland)를 사용하였다.

\section{결과}

\section{1. 설문결과}

설문을 의뢰한 52 개 기관이 모두 응답하였고, 그 중 충실하 지 않은 답지를 작성한 1 개 기관을 제외하고 총 51 개 기관의 답지를 통계분석에 사용하였다.

1) 혈액은행검사실의 현황

설문에 참여한 51 개 기관은 39 개의 대학병원, 12 개의 종 
Journal of LABORATORY MEDICINE and QUALITY ASSURANCE

You La Jeon et al • Factors for Hemagglutinations in Tube Method

합병원이었으며, 그 중 37 개 기관은 $\mathrm{ABO}$ 혈액형 검사건수 가 월 1,000 건 이상이었다. 대부분의 기관에서 검사자 2 인 이 혈구형, 혈청형 검사를 각각 시행하여 혈액형 결과를 확인 하지만, 5 개 $(9.8 \%)$ 기관은 검사자 1 인이 혈구형, 혈청형 검 사를 시행하고 있었다. $\mathrm{ABO}$ 검사수행과 판독에 대한 교육 이 1년에 1회 미만으로 이루어지는 기관(3.9\%)도 일부 있었 고, $30 \%$ 의 기관에서는 시험관법의 응집 판독기준에 대한 이 미지를 작업장에 부착하고 있지 않다고 답하였다. 원심분리기 는 한일의 SEROSPIN, KUBOTA의 KA2200, DIAMED의 DIACENT-12를 비슷한 분포로 사용하고 있는 것으로 파악되 었다.

\section{2) 혈구형 검사방법 및 판독}

혈구형 검사를 시험관법으로 시행하거나 자동화장비 의 보조검사로 사용하고 있는 42 개 기관이 설문에 답하였 다(Table 3). 검체 용기는 plain tube를 $45 \%$ 의 기관이, ethylenediaminetetraacetic acid tube를 $55 \%$ 의 기관이 사용 하고 있었고, 검체의 보관은 1 개 기관을 제외하고는 검사 전까 지 실온에 보관하였으며, 약 $70 \%$ 의 기관이 검체 도착 후 1 시 간 이내에 검사를 하는 것으로 파악되었다. 플라스틱과 유리 재질의 시험관을 각각 $45 \%, 52 \%$ 의 기관에서 사용하고 있었 고, 시험관 길이는 $7.5 \mathrm{~cm}$ 에 직경이 10-12 mm로 시험관 규격 에 있어 큰 차이는 없었다. 각 검체의 혈구액 채취방법이 다양 하였는데, 세척과정 없이 생리식염수로 $2 \%-5 \%$ 농도로 희석 하는 경우(38.1\%)와 원검체의 혈구층에서 바로 채취하여 사 용하는 경우 $(28.6 \%)$ 가 비교적 많았다. 혈구액과 항혈청시약 의 비율은 각 기관에서 시험관에 넣는 방울 수로 응답을 받아 추후에 비를 계산하였으며, $86 \%$ 의 기관이 $1: 1$ 의 비율을 사용 했지만 일부 기관은 항혈청시약을 2 배로 넣기도 하고, 한 기관 은 혈구액을 2 배 넣어 $2: 1$ 의 비율로 사용하고 있었다. 원심은 $90 \%$ 의 기관이 3,000-3,500 rpm에서 15-30초 정도 시간으로 하였으며, 세부 프로토콜은 장비마다 매우 다양하였다. 단순 침전과의 구별을 위해 먼저 살짝 기울여 미세한 응집 여부를 관찰하고, $30^{\circ}$ 미만 각도에서 약하게 1-4회 흔든 후 관찰하는 방식이 가장 많은 것으로 나타났다. 결과입력 시에는 응답기관 의 반 정도(22/42)가 응집강도는 표기하지 않고 혈액형만 입 력한다고 하였고, 응집강도를 표기하는 기관 중에는 (음성 [-], trace[ \pm$]$ 약 $4+)$ 로 기록하는 기관이 $75 \%$ (15/20)였다.

\section{3) 혈청형 검사방법 및 판독}

혈청형 검사에 대한 응답은 총 51 개 기관이 하였으며, 혈장 을 사용하는 기관이 혈청을 사용하는 기관보다 $20 \%$ 정도 더
Table 3. Results of a survey of cell typing test by the tube method (total=42)

\begin{tabular}{|c|c|}
\hline Factor & $\begin{array}{c}\text { No. of } \\
\text { laboratories } \\
(\%)\end{array}$ \\
\hline \multicolumn{2}{|l|}{ Blood collection tubes } \\
\hline Plain tube (plastic) & $14(33.3)$ \\
\hline Plain tube (glass) & $5(11.9)$ \\
\hline Ethylenediaminetetraacetic acid tube & $23(54.8)$ \\
\hline \multicolumn{2}{|l|}{ Material types of tube } \\
\hline Plastic & $19(45.2)$ \\
\hline Glass & $22(52.4)$ \\
\hline Other & $1(2.4)$ \\
\hline \multicolumn{2}{|l|}{ Tube size (diameter, length) } \\
\hline $10 \mathrm{~mm}, 7.5 \mathrm{~cm}$ & $21(50.0)$ \\
\hline $12 \mathrm{~mm}, 7.5 \mathrm{~cm}$ & $15(35.7)$ \\
\hline Others & $6(14.3)$ \\
\hline \multicolumn{2}{|l|}{ Red cell suspension as specimen } \\
\hline Direct sampling from the red cell layer & $12(28.5)$ \\
\hline Mixed with serum and red cell layer & $6(14.3)$ \\
\hline $2 \%-5 \%$ red cell suspension without saline washing & $16(38.1)$ \\
\hline $2 \%-5 \%$ red cell suspension with saline washing & $7(16.7)$ \\
\hline Other & $1(2.4)$ \\
\hline \multicolumn{2}{|l|}{ Ratio of specimen to antisera } \\
\hline $1: 2$ & $5(11.9)$ \\
\hline $1: 1$ & $36(85.7)$ \\
\hline $2: 1$ & $1(2.4)$ \\
\hline \multicolumn{2}{|l|}{ Commercial antisera } \\
\hline BIOSCOT (Millipore) & $22(52.4)$ \\
\hline NOVACLONE (Dominion) & $9(21.4)$ \\
\hline SIHDIA (Shinyang) & $8(19.0)$ \\
\hline BIOCLONE (Ortho) & $2(4.8)$ \\
\hline Other & $1(2.4)$ \\
\hline \multicolumn{2}{|l|}{ Centrifugation (rpm, sec) } \\
\hline $1,500,15$ & $3(7.1)$ \\
\hline $2,000,30$ & $1(2.4)$ \\
\hline $3,000,15$ & $11(26.2)$ \\
\hline $3,000-3500,15-30$ & $27(64.3)$ \\
\hline \multicolumn{2}{|l|}{ Shaking tube before interpretation (angle, times)* } \\
\hline$<30^{\circ}, 1-4$ & $22(52.4)$ \\
\hline$<30^{\circ}, 5-10$ & $4(9.5)$ \\
\hline$>30^{\circ}, 1-4$ & $1(2.4)$ \\
\hline$>30^{\circ}, 5-10$ & $1(2.4)$ \\
\hline Combination & $11(26.2)$ \\
\hline
\end{tabular}

${ }^{\star}$ Three laboratories answered insufficiently. 
많았다(Table 4). 검사 시작 전 보관환경이나 소요시간, 시험 관 재질이나 규격 등은 앞선 혈구형 검사의 응답과 거의 유사 하였고, 혈구시약과 검체의 비율은 대부분의 기관이 $1: 2$ 로 하 고 있었으며, 검체를 희석하여 사용하는 기관은 없었다. 20 개 기관은 혈구시약을 직접 제조하여 사용하였으며, 31 개 기관은 시판용 혈구시약을 사용하였는데, 그 중 22 개 기관이 Ortho 사의 제품을, 나머지 기관에서는 미르싸이텍, DIAGAST, $\mathrm{BIORAD}$ 순으로 사용하고 있었다. 원심은 3,000-3,500 rpm, 15-30초로 사용하였고, 시험관 흔드는 방식도 혈구형 검사와 마찬가지로 미세한 응집 관찰 후 $30^{\circ}$ 미만 각도에서 약하게 흔 든 후 관찰하는 방식이 다수였다. 거의 모든 기관은 혈구형 검

Table 4. Results of a survey of serum typing test by the tube method (total=51)

\begin{tabular}{|c|c|}
\hline Factor & $\begin{array}{c}\text { No. of } \\
\text { laboratories } \\
(\%)\end{array}$ \\
\hline \multicolumn{2}{|l|}{ Specimen } \\
\hline Plasma & $30(58.9)$ \\
\hline Serum & $21(41.1)$ \\
\hline \multicolumn{2}{|l|}{ Material types of tube } \\
\hline Plastic & $22(43.1)$ \\
\hline Glass & $28(54.9)$ \\
\hline Other & $1(2.0)$ \\
\hline \multicolumn{2}{|l|}{ Tube size (diameter, length) } \\
\hline $10 \mathrm{~mm}, 7.5 \mathrm{~cm}$ & $25(49.0)$ \\
\hline $12 \mathrm{~mm}, 7.5 \mathrm{~cm}$ & $17(33.3)$ \\
\hline Other & $9(17.7)$ \\
\hline \multicolumn{2}{|c|}{ Ratio of reagent (red cell suspension) to specimen } \\
\hline $1: 1$ & $12(23.5)$ \\
\hline $1: 2$ & $34(66.7)$ \\
\hline $2: 2$ & $5(9.8)$ \\
\hline \multicolumn{2}{|l|}{ Centrifugation (rpm, sec) } \\
\hline $1,500,15$ & $3(5.9)$ \\
\hline $2,500,30$ & $1(2.0)$ \\
\hline $3,000,15$ & $12(23.5)$ \\
\hline $3,000-3,500,15-30$ & $35(68.6)$ \\
\hline \multicolumn{2}{|c|}{ Shaking tube before interpretation (angle, times)* } \\
\hline$<30^{\circ}, 1-4$ & $23(45.1)$ \\
\hline$<30^{\circ}, 5-10$ & $10(19.6)$ \\
\hline$>30^{\circ}, 1-4$ & $4(7.8)$ \\
\hline$>30^{\circ}, 5-10$ & $2(3.9)$ \\
\hline Combination & $7(13.7)$ \\
\hline
\end{tabular}

${ }^{\star}$ Five laboratories answered insufficiently.
사와 비슷하게 관찰하는 방식을 택하였지만, 3 개 기관에서는 혈청형 검사보다 혈구형 검사에서 흔드는 각도를 넓히거나 강 도를 강하게 하는 방식을 취하였다.

\section{4) 혈구시약의 제조방법}

혈구시약 제조방법에 관한 설문은 직접 제조한 시약으로 실 제 검사에 사용하는 20 개의 기관과 보조용으로만 사용하거나 최근까지 제조한 시약을 사용하였던 3 개의 기관, 즉 23 개 기관 이 답하였다(Table 5). 재료로는 수혈용 농축적혈구의 분절을 사용하는 기관이 조금 더 많았고, 대부분 선별 시점 또는 제조 후 항-A, 항-B를 확인하였다. 혈구 선별 시 추가검사로는 응 답기관의 $50 \%$ 정도가 혈구의 $\mathrm{Rh}$ 표현형 검사를 하고 있었고, 그 외 직접항글로불린검사, 비예기항체 선별검사, 항-A1 검사 등을 시행하는 기관도 상당수 있었다. 응답한 기관 중 1 개 기 관은 선택지에 있는 모든 검사를 시행한다고 하였으며, 2 개 기 관은 추가검사를 전혀 시행하지 않는다고 답하였다. 23개 기 관 중 22 개 기관이 혈구시약 제조 전에는 3 회 이상 세척을 하 고, $0.9 \%$ 생리식염수로 희석하는 것으로 파악되었다. 혈구시 약의 농도는 혈구농축액과 희석용 용액의 용량을 직접 답하도 록 하고 추후 이를 계산하였는데, 19 개(83\%)의 기관이 $2 \%$ $5 \%$ 농도가 되도록 제조하고 있었다. 농도가 $2 \%$ 미만인 곳이 2 개 기관이었고, 한 기관은 농도가 $9.1 \%$ 였다. 혈구시약 사용 일은 $80 \%$ 의 기관이 1 주일 이내로 사용하고 있다고 답하였고, 나머지 5 개 기관은 8 일 이상 사용한다고 답하였다. 제조한 혈 구시약의 보관용기는 응답기관의 15 개 기관이 일반 혈청분리 관을, 8 개 기관이 유리용기에 보관하고 스포이드를 사용한다 고 답하였다.

\section{2. 실험결과}

Tables 1, 2에 제시한 바와 같이 실험하였으며, 결과는 다음 과 같았다. 응집강도가 기준방법의 결과와 1 titer 이상 차이를 보이면 검사방법에 따른 차이가 있는 것으로 보았다.

\section{1) 혈구형 검사}

혈구형 검사에 사용한 검체의 혈액형 분포는 $\mathrm{A}$ 형이 15 개, $\mathrm{Aw}$ 형이 1개, B형이 20개, $\mathrm{AB}$ 형이 4개였다(Table 6). 혈구 형 검사의 응집결과에 가장 큰 영향을 미치는 요인은 혈구액 채취방법이었다. 혈구액을 혈구층에서 직접 채취한 경우, 6 개 $(15 \%, \mathrm{~A}$ 형 3 검체, $\mathrm{B}$ 형 1 검체, $\mathrm{AB}$ 형 2검체 $)$ 검체의 응집이 기준보다 2 titer 낮게 관찰되었고, $62.5 \%$ 인 25 개의 검체에서 1 titer 낮게 관찰되었다. 또한 각도에 상관없이 1-4회 흔든 후 관찰한 경우 $\mathrm{Aw}$ 형 검체에서 2 titer 높게 관찰되었다. 그밖에 


\section{Journal of LABORATORY MEDICINE and QUALITY ASSURANCE}

You La Jeon et al • Factors for Hemagglutinations in Tube Method

Table 5. Red cell suspension preparation (reagent) (total=23)

\begin{tabular}{|c|c|}
\hline Procedure & $\begin{array}{c}\text { No. of } \\
\text { laboratories } \\
(\%)\end{array}$ \\
\hline \multicolumn{2}{|l|}{ Specimen } \\
\hline Segment of packed RBC & $14(60.9)$ \\
\hline $\begin{array}{l}\text { Ethylenediaminetetraacetic acid blood specimen } \\
\text { from healthy individual }\end{array}$ & $9(39.1)$ \\
\hline \multicolumn{2}{|l|}{ Tests for selection of adequate erythrocytes } \\
\hline $\begin{array}{l}\text { Anti-A and anti-B of prepared red cell } \\
\text { suspension }\end{array}$ & $13(56.5)$ \\
\hline $\begin{array}{l}\text { Anti-A1 and anti-B of prepared red cell } \\
\text { suspension }\end{array}$ & $3(13.0)$ \\
\hline Anti-A and anti-B of selected specimen & $7(30.4)$ \\
\hline Anti-A1 and anti-B of selected specimen & 0 \\
\hline \multicolumn{2}{|l|}{$\begin{array}{l}\text { Additional tests for selection of adequate } \\
\text { erythrocytes (contained multiple selected } \\
\text { responses) }\end{array}$} \\
\hline Direct antiglobulin test (direct Coombs test) & $9(39.1)$ \\
\hline Unexpected antibody screening test $\left(37^{\circ} \mathrm{C}\right)$ & $8(34.8)$ \\
\hline Unexpected antibody screening test $\left(4^{\circ} \mathrm{C}\right)$ & $4(17.4)$ \\
\hline Check the response anti-A1 & $8(34.8)$ \\
\hline $\mathrm{Rh}$ phenotyping test & $10(43.5)$ \\
\hline Other & $1(4.3)$ \\
\hline None & $2(8.7)$ \\
\hline \multicolumn{2}{|l|}{ Step of washing the red cells } \\
\hline $1-2$ times & $1(4.3)$ \\
\hline More than 3 times & $22(95.7)$ \\
\hline \multicolumn{2}{|l|}{ Dilution solution } \\
\hline $0.9 \% \mathrm{NaCl}$ & $22(95.7)$ \\
\hline Other (BIORAD stabilizing solution) & $1(4.3)$ \\
\hline \multicolumn{2}{|l|}{ Concentration of red cell suspension } \\
\hline$<1 \%$ & $1(4.3)$ \\
\hline $1 \%-2 \%$ & $1(4.3)$ \\
\hline $2 \%-3 \%$ & $4(17.5)$ \\
\hline $3 \%-5 \%$ & $15(65.3)$ \\
\hline$>5 \%(9.1 \%)$ & $1(4.3)$ \\
\hline $\begin{array}{l}\text { Comparison with commercialized reagent by } \\
\text { naked eye }\end{array}$ & $1(4.3)$ \\
\hline \multicolumn{2}{|l|}{ Validity date } \\
\hline Only on day of preparation & $1(4.3)$ \\
\hline $2-4$ days & $10(43.5)$ \\
\hline 5-7 days & $7(30.5)$ \\
\hline Over 8 days & $5(21.7)$ \\
\hline
\end{tabular}

시험관 재질, 항혈청시약의 종류, 혈구액과 시약의 비율 등은 응집결과에 영향을 주지 않았다.

\section{2) 혈청형 검사(희석 검체 제외)}

혈청형 검사의 응집결과에 미치는 영향인자는 혈구형 검사 에 비해 다양하였다. 혈구시약 대비 혈청의 비율을 $1: 1$ 로 한 경우 $23.3 \%$ 의 검체에서 $1: 2$ 비율로 검사한 것에 비해 1 titer 낮은 결과를 보였다(Table 6). 제조한 혈구시약의 농도가 $2 \%$ 또는 $5 \%$ 일 때, 또는 기준과 같은 $3.85 \%$ 이나 제조일이 7 일을 경과하였을 때 응집강도가 1-2 titer 낮아지는 것을 알 수 있 었다. 가장 많은 영향을 미친 인자는 응집 판독 전에 시험관 을 흔드는 횟수였는데, 각도에 상관없이 5-10회 흔들었을 때 총 21개(70.0\%) 검체의 결과가 기준에 비해 1-2 titer 낮게 판 독되었다. 그 밖에 원심을 2,000 rpm에 15초로 적용한 경우 (13.3\%)에서 일부 검체들이 1 titer 낮은 결과를 보였다.

\section{3) 혈청형 검사(희석 검체)}

혈청형 검사에서 항체 역가가 낮은 경우에 어떤 영향이 있 는지 조사하기 위해 10 개 검체를 희석하여 실험하였다(Table 7). 희석 검체를 이용한 검사에서도 혈구시약의 농도가 너무 낮거나 높은 경우 또는 자가 제조 후 7일 이상 경과한 경우 등 이 검체 응집결과에 영향을 미쳤다. 또한 판독 전 흔드는 횟수 에 따른 영향을 가장 많이 받았고, 각도에 상관없이 5-10회 흔 든 경우 10 개 중 6 개(60\%) 검체에서 응집강도가 1-2 titer 낮 게 판독되었고, 흔드는 횟수를 1-4회로 기준과 동일하게 하였 지만 $30^{\circ}$ 이상 각도를 적용한 경우는 $30 \%$ 의 검체에서 1 titer 낮은 응집을 보였다. 원심 프로토콜을 $2,000 \mathrm{rpm}$ 에 15초로 적 용했을 때 $30 \%$ 의 검체가 기준보다 1-2 titer 낮은 결과를 보였 다.

\section{고찰}

혈액형 검사에서 시험관법은 2015년 외부 숙련도조사에 참 여한 대부분의 기관이 시행하고 있는 검사법이다[3]. 본 연구 에서는 수혈의학 교과서에 제시된 혈구형 및 혈청형 검사의 시 험관법검사에서 혈구액 농도나 혈구액과 항혈청 또는 혈구시 약과 혈청의 비율, 원심 프로토콜을 포함하여 자세한 과정에 대한 설문을 하였다. 그 결과, 검사에 사용하는 시험관 재료나 검체, 검사방법, 판독방법이 통일되어 있지 않았고, 교과서에 제시된 것과 다른 방법으로 검사하는 기관도 있었다.

예를 들면 혈구형 검사에서 혈구 검체는 $2 \%-5 \%$ 농도의 혈 구부유액을 만들어 검사하도록 안내하고 있으나 설문에 응한 
Journal of LABORATORY MEDICINE and QUALITY ASSURANCE

You La Jeon et al • Factors for Hemagglutinations in Tube Method

Table 6. Effects of various factors on hemagglutination

\begin{tabular}{|c|c|c|}
\hline Factors & $\begin{array}{c}\text { No. of specimens } \\
\text { representing differences (\%) }\end{array}$ & $\begin{array}{c}\text { Differences in } \\
\text { hemagglutination strength }\end{array}$ \\
\hline \multicolumn{3}{|c|}{ Cell typing on 40 specimens (blood group: $A=15, A w=1, B=20, A B=4$ ) } \\
\hline \multicolumn{3}{|l|}{ Red cell suspension } \\
\hline \multirow[t]{4}{*}{ Direct sampling from the red cell layer } & $32(80.0)$ & \\
\hline & $25(62.5)$ & $\boldsymbol{\nabla}$ \\
\hline & $6(15.0)$ & $\nabla \nabla$ \\
\hline & $1^{*}(2.5)$ & $\triangle$ \\
\hline Mixed with serum and red cell layer & $11(27.5)$ & $\boldsymbol{\nabla}$ \\
\hline \multicolumn{3}{|l|}{ Shaking } \\
\hline$<30^{\circ}, 1-4$ & $1^{\star}(2.5)$ & $\triangle \triangle$ \\
\hline$>30^{\circ}, 1-4$ & $1^{*}(2.5)$ & $\triangle \triangle$ \\
\hline Centrifugation $(2,000 \mathrm{rpm}, 15 \mathrm{sec})$ & $1^{\star}(2.5)$ & $\nabla$ \\
\hline \multicolumn{3}{|c|}{ Serum typing on 30 specimens (blood group: $A=6, B=14, O=10$ ) } \\
\hline Ratio of reagent (red cell suspension) to specimen 1:1 & $7(23.3)$ & $\nabla$ \\
\hline \multicolumn{3}{|l|}{ Red cell suspension } \\
\hline \multirow[t]{3}{*}{$2 \%$} & $5(16.7)$ & \\
\hline & $4(13.3)$ & $\nabla$ \\
\hline & $1(3.3)$ & $\boldsymbol{\nabla}$ \\
\hline $5 \%$ & $4(13.3)$ & $\nabla$ \\
\hline $3.85 \%$ (7 days after preparation) & $6(20.0)$ & $\nabla$ \\
\hline \multicolumn{3}{|l|}{ Shaking } \\
\hline \multirow[t]{3}{*}{$<30^{\circ}, 5-10$} & $4(13.3)$ & \\
\hline & $2(6.7)$ & $\nabla$ \\
\hline & $2(6.7)$ & $\nabla \nabla$ \\
\hline$>30^{\circ}, 1-4$ & $2(6.7)$ & $\nabla$ \\
\hline \multirow[t]{3}{*}{$>30^{\circ}, 5-10$} & $17(56.7)$ & \\
\hline & $12(40.0)$ & $\nabla$ \\
\hline & $5(16.7)$ & $\nabla \nabla$ \\
\hline \multirow[t]{3}{*}{ Material types of tube (plastic) } & $3(10.0)$ & \\
\hline & $2(6.7)$ & $\boldsymbol{\nabla}$ \\
\hline & $1(3.3)$ & $\nabla \nabla$ \\
\hline Specimen (plasma) & $1(3.3)$ & $\nabla$ \\
\hline Centrifugation $(2,000 \mathrm{rpm}, 15 \mathrm{sec})$ & $4(13.3)$ & $\nabla$ \\
\hline
\end{tabular}

${ }^{*}$ Weak subtype of blood group A.

일부 기관들은 원검체의 혈구층에서 바로 채취하여 사용하였 다[7]. 이 방법은 슬라이드법에서 사용했던 방법으로, 슬라이 드법에서 시험관법으로 전환하면서 혈구액 채취방법을 변경 하지 않았을 가능성이 있다. 실험에서도 확인하였지만, 원검 체 혈구액은 과량의 혈구가 포함되어 있으므로 항혈청의 항체 에 비해 적혈구 항원의 비율이 높아져 최적의 응집을 방해하고
[1], 아형에서는 항원량이 적어 약하게 나타나야 하는 응집을 강하게 하여 판독에 오류를 가져올 수 있다. 그러므로 혈구형 검사 시에 혈구액을 원검체에서 직접 채취하는 방법은 정확한 판독을 위해 지양해야 한다.

또한 원심 프로토콜의 경우 $3,400 \mathrm{rpm}$ 에 15 초를 안내하 고 있지만, 기관마다 사용하는 프로토콜이 다양하였다. 같 
Journal of LABORATORY MEDICINE and QUALITY ASSURANCE

You La Jeon et al • Factors for Hemagglutinations in Tube Method

Table 7. Effects of various factors on hemagglutination in diluted serum (10 specimens)

\begin{tabular}{|c|c|c|}
\hline Factors & $\begin{array}{l}\text { No. of specimens } \\
\text { representing } \\
\text { differences }(\%)\end{array}$ & $\begin{array}{c}\text { Differences in } \\
\text { hemagglutination } \\
\text { strength }\end{array}$ \\
\hline \multirow{3}{*}{$\begin{array}{l}\text { Ratio of reagent } \\
\text { (red cell suspension) } \\
\text { to specimen } 1: 1\end{array}$} & $3(30.0)$ & $\nabla$ \\
\hline & $2(20.0)$ & $\nabla$ \\
\hline & $1(10.0)$ & $\nabla \nabla$ \\
\hline \multicolumn{3}{|l|}{ Red cell suspension } \\
\hline \multirow[t]{3}{*}{$2 \%$} & $4(40.0)$ & \\
\hline & $2(20.0)$ & $\nabla$ \\
\hline & $2(20.0)$ & $\nabla \nabla$ \\
\hline \multirow[t]{3}{*}{$5 \%$} & $6(60.0)$ & \\
\hline & $5(50.0)$ & $\nabla$ \\
\hline & $1(10.0)$ & $\nabla \nabla$ \\
\hline \multirow{3}{*}{$\begin{array}{l}3.85 \% \text { (7 days after } \\
\text { preparation) }\end{array}$} & $5(50.0)$ & \\
\hline & $4(40.0)$ & $\nabla$ \\
\hline & $1(10.0)$ & $\nabla \nabla$ \\
\hline \multicolumn{3}{|l|}{ Shaking } \\
\hline$<30^{\circ}, 5-10$ & $6(60.0)$ & $\nabla$ \\
\hline$>30^{\circ}, 1-4$ & $3(30.0)$ & $\nabla$ \\
\hline \multirow[t]{3}{*}{$>30^{\circ}, 5-10$} & $6(60.0)$ & \\
\hline & $4(40.0)$ & $\nabla$ \\
\hline & $2(20.0)$ & $\nabla \nabla$ \\
\hline $\begin{array}{l}\text { Material types of tube } \\
\text { (plastic) }\end{array}$ & $2(20.0)$ & $\nabla$ \\
\hline Specimen (plasma) & $1(10.0)$ & $\nabla$ \\
\hline \multirow{3}{*}{$\begin{array}{l}\text { Centrifugation } \\
(2,000 \mathrm{rpm}, 15 \mathrm{sec})\end{array}$} & $3(30.0)$ & \\
\hline & $2(20.0)$ & $\nabla$ \\
\hline & $1(10.0)$ & $\nabla \nabla$ \\
\hline
\end{tabular}

은 rpm을 적용해도 장비에 따라 $\mathrm{g}$ 값이 달라질 수 있어 정 확한 분석은 어렵지만, 본 연구에서 동일 장비로 $3,000 \mathrm{rpm}$ 과 $2,000 \mathrm{rpm}$ 에 각각 15 초간 원심한 결과 $2,000 \mathrm{rpm}$ 으로 원 심을 했을 때 아형 검체에서 응집강도가 약하게 나타났다. 원 심 프로토콜에 따른 영향은 혈청형 검사에서도 일부 나타났 고, 희석 혈청을 사용한 혈청형 검사에서는 $30 \%$ 에 해당하 는 검체가 1-2 titer 낮은 응집강도를 보였다. 원심과정은 적 혈구 표면의 음성 전하 때문에 서로 밀어내는 것을 이겨내고 immunoglobulin-G에 의한 응집을 가능하게 하여 혈구 응집
강도에 직접적인 영향을 미친다[1]. 그러므로 혈구 응집강도 가 타 기관에 비해 낮은 경향을 보인다면 원심 프로토콜도 점 검해 볼 필요가 있고, 항체 역가가 낮은 검체라면 더욱 영향을 받으므로 적용하고 있는 프로토콜이 적정한지 확인해야 한다.

그밖에 혈청형 검사결과에 영향을 미치는 요인은 혈구형 검 사에 비해 더욱 다양한 것으로 분석되었다. 혈구시약 대비 혈 청의 비율이 낮거나, 자가제조한 혈구시약의 농도가 낮거나 높 은 경우, 또는 7일 이상 경과된 경우에 혈구응집의 강도가 낮 아지고, 특히 희석한 검체에서는 그 영향이 더욱 뚜렷하였다. 특히 고령이나 면역결핍성 질환 또는 면역결핍상태로 항체 역 가가 낮은 경우에 판독에 오류가 생길 수 있으므로 혈액은행검 사실마다 이에 대한 점검이 필요하다[8-11]. 그러므로 제조하 는 혈구시약의 농도를 $3 \%$ 에 가깝게 맞추고, 혈구시약과 혈청 의 비율은 $1: 2$ 로 해야 적절한 혈구응집을 유도할 수 있을 것으 로 생각된다.

사용일에 대해서는 본 연구에서는 최소한 7일 이상 사용하 면 응집강도가 낮아질 수 있음을 확인하였는데, 혈구시약 제조 후 시일에 따른 $\mathrm{ABO}$ 항체 역가를 비교한 연구에서 시험관법 의 경우 6 일째부터, 겔카드법의 경우 5 일째부터 역가가 유의 하게 낮아지는 것으로 보고하였다[12]. 또한 $\mathrm{AABB}$ 에서는 성 능에 대한 적절한 검증을 하지 않는다면 당일 제조한 것을 사 용하도록 안내하고 있어, 2 일 이상 사용할 경우 일반 시약과 마찬가지로 사용 전에 정도관리를 하여 그 반응이 제조 당일과 동일한 지 확인한 후 사용해야 할 것이다[1].

한편, 혈구시약의 자가제조 시에 시약으로서의 적정성 확인 을 위한 검사에 대한 설문조사결과는 기관마다 매우 상이하여 추가검사를 전혀 실시하지 않는 기관도 있었고, 보기에 제시 한 모든 검사를 시행하는 기관도 있었다. 이에 대한 권고사항 도 아직까지 정립되어 있지 않다. 다만, 혈구를 선택할 때 혈액 형이 같은 여러 혈액에서 채취하여 섞는다면 Rh항원을 비롯 한 적혈구 항원형이 다양해지고 항원양은 상대적으로 낮아져 $\mathrm{ABO}$ 를 제외한 다른 항원-항체반응에 의한 간섭이 줄어들 수 있다[12]. 또한 국내 $\mathrm{ABO}$ 혈액형 검사용 시약의 허가 및 심사 가이드라인에서 시판용 혈구시약의 시험규격에 직접항글로불 린검사에 음성일 것을 요구하고 있으므로 자가제조 시약에서 도 이에 대한 확인은 필요할 것으로 생각된다[13].

본 연구는 설문분석 대상기관이 51 개 기관으로 설문이 한정 적으로 이루어졌다는 것과, 항원이 약한 아형 혈액의 검출에 있어 혈구 응집강도에 미치는 영향인자분석이 중요함에도 아 형 혈액형 검체가 소수만 포함되었다는 제한점이 있다.

본 연구를 통해 시험관을 이용한 $\mathrm{ABO}$ 혈액형 검사에서 정확 한 혈구응집결과를 얻기 위해서는 검체용 혈구부유액이나 제 
조하는 혈구시약의 경우 $2 \%-5 \%$ 이내의 농도로 제조하고, 혈 구시약의 경우 제조 당일이 아닌 경우 응집강도 확인 후 사용 하되 최소한 7일을 넘기지 않도록 하며, 제조 시 여러 혈액을 섞어 사용하고 최소한 직접항글로불린검사 결과가 음성임을 확인해야 함을 알 수 있다. 적정 원심 프로토콜을 적용하고 있 는지 점검하고 원심 후 적당한 각도와 강도로 시험관을 흔들어 확인하는 과정도 필요하다.

또한 다수의 기관이 사용하고 있는 혈액형 검사법인 시험관 법의 검사과정에 대한 자세한 지침의 정립이 필요함을 알 수 있었으며, 현재 혈액안전사업단에서 시행하고 있는 응집강도 분석프로그램을 통해 기관마다 동일한 결과를 도출할 수 있도 록 하는 노력이 요구된다.

\section{감사의 글}

이 논문은 대한임상검사정도관리협회 2017년 학술연구비 지원에 의해 이루어졌다(2017-08).

\section{REFERENCES}

1. Fung MK, Eder A, Spitalnik SL, Westhoff CM. Technical manual. 19th ed. Bethesda (MD): American Association of Blood Banks, 2017.

2. Mujahid A, Dickert FL. Blood group typing: from classical strategies to the application of synthetic antibodies generated by molecular imprinting. Sensors (Basel) 2015;16:E51.

3. Lim YA, Cho HS, Choi YS, Jang CH, Lee MN, Kwon JR, et al. Report on external proficiency testing for the $\mathrm{ABO}$ and D blood group typing tests in blood centers (2015). Korean J Blood Transfus 2016;27:68-78.

4. Black D, Kay J. Influence of tube type on the antiglobulin test. Med Lab Sci 1986;43:169-73.

5. Reid ME, Bottenfield LK, Toy PT, Ellisor SS, Hart CA. Agglutination of an EDTA blood sample caused by an EDTA-dependent panagglutinin. Am J Clin Pathol 1985;83: 534-5.

6. Greendyke RM, Wormer JL, Banzhaf JC. Quality assurance in the blood bank: studies of technologist performance. Am J Clin Pathol 1979;71:287-90.

7. Han KS, Park KW, Song EY. Transfusion medicine. 4th ed. Seoul: Korea Medical Book Publisher, 2014.

8. Mavichak W, Chiewsilp P, Tubrod J, Ovataga P. ABO antibodies among group $\mathrm{O}$ Thai blood donors. J Hematol Transfus Med 2013;23:203-9.

9. Martin CM, Gordon RS, McCullough NB. Acquired hypogammaglobulinemia in an adult; report of a case, with clinical and experimental studies. N Engl J Med 1956;254:449-56.

10. Oh SH, Kang CI, Kim J, Park TS. ABO discrepancy in a young Korean serviceman with common variable immunodeficiency. Ann Hematol 2010;89:629-30.

11. Julius CJ, Wade M, Waheed A, McNeil DL, Kennedy MS. Common variable immunodeficiency: diagnosis by absent ABO reverse type. Immunohematology 1997;13:803.

12. Kang SJ, Cho SR, Lim YA. Optimum conditions for the preparation of red blood cell suspensions for $\mathrm{ABO}$ antibody titration. Lab Med Online 2015;5:15-9.

13. Ministry of Food and Drug Safety. In vitro medical devices: guideline on test and performance evaluation for $\mathrm{ABO}$ blood grouping reagents. Cheongju: Ministry of Food and Drug Safety, 2015. 
Journal of LABORATORY MEDICINE and QUALITY ASSURANCE

You La Jeon et al • Factors for Hemagglutinations in Tube Method

시험관법을 이용한 $\mathrm{ABO}$ 혈액형 검사에서 혈구 응집정도에 영 향을 미치는 요인분석

전유라 ${ }^{1}$ 이우인 $1^{1,2}$ • 강소영, ${ }^{1,2}$ 김명희 ${ }^{1,2}$

'강동경희대학교병원 진단검사의학과, ${ }^{2}$ 경희대학교 의과대학 진단검사의학교실

배경: $\mathrm{ABO}$ 혈액형 검사는 혈구응집을 기본으로 하며, 가장 먼저 시행되는 수혈 전 검사이다. 혈구 응집에 영향을 미치는 변수는 다양하지만 임상검사실에서 어떻게 적용하고 있고, 실제 응집에 어떤 영향을 미치는 지에 대한 연구는 부족한 상황이다. 본 연구는 다수의 기관이 사용하고 있는 시험관 법을 이용한 $\mathrm{ABO}$ 혈액형 검사과정 중에서 혈구 응집강도에 영향을 미치는 인자를 분석하였다.

방법: 51 개 기관에 대해 혈구형, 혈청형 검사과정에 대한 자세한 설문조사를 시행하였다. 각 검사 과정 중 혈구 응집강도에 영향을 미칠 수 있고 기관마다 상이하게 적용하고 있는 몇 개의 변수를 지정하여 혈구형 검사 10 가지, 혈청형 검사 11 가지의 조건을 만들었다. 혈구형 검사 40 개, 혈청형 검사 40 개 검체를 각각의 조건에 따라 실험한 후 응집강도를 비교, 분석하였다.

결과: 설문결과, 검체로 사용하는 혈구부유액 제조방법, 사용되는 시험관 규격과 재료, 원심방법, 혈구시약 제조방법, 검사 시 검체와 항혈청시약 또는 혈구시약과 혈청 비율, 원심 후 판독 전에 시 험관을 흔드는 방법 등이 기관마다 매우 다양하였다. 이를 실험에 반영하여 혈구형 검사와 혈청형 검사 후 응집결과를 분석한 결과, 혈구형 검사에서는 검체인 혈구액을 혈구층에서 직접 채취하여 바로 사용한 경우에 다수의 검체에서 응집강도가 약하게 나타났다. 혈청형 검사에서는 시험관 흔드 는 방법이나 자가제조한 혈구시약의 농도를 비롯해 다양한 요인들이 응집강도에 영향을 미쳤다.

결론: 정확한 혈액형 검사를 위해 본 연구에서 밝혀진 시험관법 시행 시 혈구 응집강도에 영향을 미치는 인자를 포함하여 자세한 검사과정 지침의 정립이 필요하다.

(J Lab Med Qual Assur 2018;40:161-170)

교신저자: 이우인

우) 05278 서울시 강동구 동남로 892 , 강동경희대학교병원 진단검사의학과

Tel: 02)440-7190, Fax: 02)440-7195, E-mail: wileemd@khu.ac.kr 